Review article

\title{
Bisphenol a and mesenchymal stem cells: Recent insights
}

\author{
Helga Caputo Nunes ${ }^{\mathrm{a}, \mathrm{b}}$, Wellerson Rodrigo Scarano ${ }^{\mathrm{a}}$, Elenice Deffune ${ }^{\mathrm{b}}$, Sérgio Luis Felisbino ${ }^{\mathrm{a}}$, \\ Immacolata Porreca $^{\mathrm{c}}$, Flávia Karina Delella ${ }^{\mathrm{a}, *}$ \\ a Department of Morphology, Institute of Biosciences, Univ Estadual Paulista - UNESP, Botucatu, Sao Paulo, Brazil \\ b Botucatu Medical School, Blood Transfusion Center, Cell Engineering Lab, Univ Estadual Paulista - UNESP, Botucatu, Sao Paulo, Brazil \\ ${ }^{\mathrm{c}}$ Human Genetics, Wellcome Trust Sanger Institute, Hinxton, United Kingdom
}

\section{A R T I C L E I N F O}

\section{Keywords:}

Obesogens

Endocrine disrupting chemicals

Adipose derived stem cells

\begin{abstract}
A B S T R A C T
Mesenchymal stem cells (MSCs) are found in all adult mesenchymal tissues. They play a role in the maintenance of tissue homeostasis and repair by allowing renewal of the cellular stock. MSCs can be isolated from both human and animal sources. These cells are important in regenerative medicine and cell therapy, thus adipose tissue is a rich and promising source of these cells. Adipose-derived stem cells (ASCs) are often effective and safe, and have been used in preclinical and clinical studies for both autologous and allogeneic transplantation. The potential use of stem cell-based therapies for the repair and regeneration of various tissues and organs provides an important alternative therapeutic solution for the treatment of many diseases. However, it is necessary to have control of the cell manipulation process prior to their use. Exposure of humans to the endocrine disruptor bisphenol A (BPA) has been associated with increased weight and obesity, but the mechanisms by which BPA increases adipose tissue in humans remains to be determined. BPA has been classified as a potent endocrine-disrupting chemical that interferes with adipogenesis. Currently, few studies have reported the effect of BPA on the integrity and capacity for differentiation of MSCs. Thus, this review aims to present, for the first time, a current survey and a discussion of the effects of BPA action on MSCs.
\end{abstract}

\section{Introduction}

\subsection{Mesenchymal stem cells}

Mesenchymal stem cells (MSCs) are a heterogeneous cell population that comprises different progenitor cells possessing the ability to repair tissues, support hematopoiesis, and regulate immune and inflammatory responses [1]. These precursors can give rise to a variety of cell types, including adipocytes, osteoblasts, chondrocytes, myocytes, $\beta$-pancreatic islets cells, and, potentially, neuronal cells [2-4]. They can be found in virtually all tissues [5]. This population was first identified and isolated from bone marrow $>40$ years ago [6]. In 2006, the International Society of Cellular Therapy established three minimum biological parameters to better identify these kind of cells, namely: (i) plastic adherence under standard in vitro culture conditions; (ii) expression of cluster of differentiation (CD) surface markers CD105, CD73, and CD90 with no expression of CD45, CD34, CD14 or CD11b, CD79a, or CD19 and HLA-DR (human leukocyte antigen-antigen D related); (iii) in vitro differentiation to osteoblasts, adipocytes, and chondrocytes [7-9]. MSCs can be expanded in vitro through consecutive passaging without significant changes to their major properties [10]. MSCs can also release chemokines and cytokines exerting paracrine effects [1]. For these reasons, this population has been extensively studied and analyzed, with the ultimate goal being to use them as cellular tools for the treatment of many types of diseases.

\subsection{Adipose derived stem cells}

As previously stated, MSCs can be found in practically all tissues [11]. However, up until 2000, adult stem cell lines appeared to derive exclusively from hematopoietic tissues [12], mesenchymal tissues [11], neural stem cells [13,14], and muscle satellite cells [15-17]. In 2001, a group from the University of California in Los Angeles (UCLA) discovered a stem cell population derived from the adipose tissue. Due to their isolation from human lipoaspirates, they were first termed "processed lipoaspirate cells", but they are now referred to as "adiposederived stem cells" (ASCs) [18]. The current term is more descriptive, as ASCs are a multi-lineage stem cell population that can be isolated from the stromo-vascular fraction of adipose tissue. In addition, in order to prove the ability of ASCs to be a multi-lineage cell population, Zuk and co-authors [18] utilized additional approaches such as the expression of multiple lineage-specific genes and functional biochemical

\footnotetext{
* Corresponding author at: Rua Professor Doutor Antonio Celso Wagner Zanin, 250, Botucatu, SP 18618-689, Brazil.

E-mail address: flavia.delella@unesp.br (F.K. Delella).
} 
assays to confirm that both differentiation capacity and clonogenicity are important requirements for identifying ASCs. When considering this issue, one of the main challenges in the identification of adult stem cells is the heterogeneity of their tissue of origin. The observed multi-lineage differentiation by ASCs may simply be due to the presence of multiple precursor populations, each completing their own developmental program [19]. Zuk's group found a way to circumvent this problem by isolating a single stem cell and obtaining proof of the cell's multi-potency. Employing this approach, they demonstrated its differentiation capacity and clonogenicity, and as a result proposed a new adult stem cell population [18]. Since 2002, many groups have confirmed the existence of these ASCs in both humans and animals [19]. Additionally, these cells also have the ability to differentiate into neuronal-like cells, and this has been confirmed by numerous studies since their first discovery [13,14,20,21].

For this reason, the use of adipose tissue-derived precursors as a therapeutic tool has grown considerably over the past years, and has triggered the growth of a new research field worldwide [22]. Regenerative medicine has evolved tremendously with these recent advances in stem cell research. The last decade has shown flashes of the astonishing potential of these cells in tissue regeneration [23]. Despite these advances, the availability of stem cells remains a challenge for both scientists and clinicians interested in regenerative medicine [24]. The main advantage of ASCs over mesenchymal stem cells derived from other sources, e.g. from bone marrow, is that they can be repeatedly harvested using minimally invasive techniques that have a low risk of morbidity [25]. Nonetheless, the ideal stem cell population should be easily accessible through a non-invasive procedure, provide an abundance of cells, be able to differentiate into a variety of cell lineages, able to be easily transplanted into an autologous or allogeneic host, and able to be manufactured in accordance with the currently accepted good manufacturing practice guidelines set by the FDA [26].

It is very well-known that our environment is contaminated with numerous chemical substances that can intrinsically alter the homeostasis and physiology of biological systems, resulting in a negative impact on human and animal health [27,28]. Concerning adipose-derived stem cells, some of these contaminating organic compounds are obesogenic but also possess the capacity to bind to hormone receptors and accumulate in fat tissue in different organisms [29]. Such molecules could well impact stem cell biology, impairing their differentiation efficiency and compromising their therapeutic use, as it has recently been reviewed for MSCs [30]. In this review, we will focus our attention on the effects of bisphenol A (BPA) on MSCs.

\subsection{Obesogens}

Obesogens are chemical compounds that can boost weight-gain by altering the number of adipocytes, increasing their ability to store fat, or by modifying several homeostatic processes [29] such as decreasing the amount of calories burned at rest, shifting the energy balance to favor the storage of calories, and modulating the mechanisms through which the body manages appetite and satiety [31]. The obesogen hypothesis has gained visibility in recent years due to the identification of obesogenic chemicals that promote adipogenesis and obesity in animals and humans [31-34]. Some of these compounds are referred to as endocrine disruptors since they interfere 'with the synthesis, secretion, transport, binding, or elimination of natural hormones' like estrogens, testosterone, and thyroid hormone, among others [35].

\subsection{Endocrine disrupting chemicals}

Endocrine disrupting chemicals (EDCs) are compounds present in our environment, food, and consumer products that interfere with the biosynthesis, metabolism, and action of hormones, resulting in alterations in the normal homeostatic or reproductive processes [36]. EDCs are produced as pesticides, plasticizers, or solvents. It was initially found that when they are absorbed into the body, they can either mimic or block hormones and disrupt the normal functions of the organism [37]. As a result, they were initially thought to exert their actions solely through nuclear hormone receptors, including estrogen receptors (ERs), androgen receptors (ARs), progesterone receptors, thyroid receptors (TRs), and retinoid receptors [36].

These substances are typically hydrophobic and lipophilic, which means that they work best in an environment that has a low concentration of water and an abundance of fatty acids. In aquatic systems and soil, EDCs are easily decanted in solids, whereas in organisms, they are partitioned into lipids. As a result, the EDCs are able to avoid being metabolized in the aqueous phase, allowing them to accumulate first in cells and fatty tissues, and then in the food chain [38].

\subsection{Bisphenol A}

Bisphenol A (BPA) is a synthetic chemical that, because of its structure, is multifaceted. The BPA (4, 4'-dihydroxy-2, 2-diphenylpropane) molecule consists of two phenol rings connected by a methyl bridge, with two methyl groups bound to the bridge [39]. BPA is classified as an endocrine disruptor, resulting in the relatively weak activation of estrogen receptor a (ERa) and b (ERb) [40-44]. BPA can also act as an antagonist of ERb [45]. This compound is used in the fabrication of polycarbonate plastic and epoxy resins, which can be used in impact-resistant safety equipment and baby bottles, as a protective coating inside metal food containers, or as a composite and sealant in dentistry [46]. This is one of the highest-volume chemicals produced globally, with 5.2 million metric tons estimated to have been produced in 2008 [47]. Because of its mass production and widespread adoption, the probability of environmental contamination with BPA has increased. Environmental contamination is possible via industrial wastewater treatment systems or sewage treatment plants that receive this compound. Other possible sources of BPA are also found in the environment, such as waste plastics in landfills and sewage sludge from wastewater treatment facilities. There is a considerable amount of monitoring of BPA levels in Europe, the United States, and Japan, and BPA has been detected in many different biological samples $[48,49]$, for example, in human blood $(<0.5-22.3 \mathrm{ng} / \mathrm{mL})[50,51]$, the serum of pregnant women $(<0.1-154 \mathrm{ng} / \mathrm{mL})[52,53]$, urine $(<0.1-822 \mathrm{ng} /$ $\mathrm{mL})$ [46,54], saliva $(0.1 \mathrm{ng} / \mathrm{mL})$, amniotic fluid $(2.80-5.62 \mathrm{ng} / \mathrm{mL})$, umbilical cord $(<0.05-52 \mathrm{ng} / \mathrm{mL})$, follicular fluid $(1-2 \mathrm{ng} / \mathrm{mL})$ [55], breast milk $(<0.04-11 \mathrm{ng} / \mathrm{mL})$ [56], and adipose tissue (1.80 to $12.01 \mathrm{ng} / \mathrm{g}$ ) [57] with BPA being principally stored in milk and adipose tissue. It has also been shown that $>90 \%$ of people tested for BPA in urine and blood tested positive [58], and that infants and children are the most affected [46].

Data from multiple sources have shown that the amount of BPA that humans are exposed to may cause adverse health effects, such as diabetes, obesity, abnormal neuronal behavior, developmental effects, and thyroid and reproductive disorders [58-61]. This has raised concerns among regulatory agencies all over the world [57]. Based on this, the United States Environmental Protection Agency (EPA) has determined a reference dose for BPA of $50 \mu \mathrm{g} / \mathrm{kg}$ body weight/day whereas the European Food Safety Authority (EFSA) have determined a reference dose of $4 \mu \mathrm{g} / \mathrm{kg}$ body weight/day [62]. In vitro, BPA has been found to cause mutagenicity in human RSa cells (a human embryonic clonal cell line established by double infection with Rous sarcoma virus and Simian virus 40) and HeLa cells [63] within the range of $100 \mathrm{nM}$ to $10 \mu \mathrm{M}$ [64]. Even though a direct genotoxic effect of BPA at low doses has not been reported, exposure to BPA at environmentally relevant doses, primarily during the developmental stages, represents a risk for carcinogenesis [62]. This compound has therefore become an environmental contaminant of considerable interest [49].

Perhaps due to BPA's shared structural homology with estrogen, it appears to be able to upregulate the expression of downstream targets, including peroxisome proliferator-activated receptor gamma (PPAR $\gamma$ ) 
and lipoprotein lipase (LPL), at least based on the results from in vitro experiments on rodents [65]. Recent studies have also demonstrated that the G protein-coupled receptor-30 (GPR-30), a transmembrane receptor structurally unrelated to the nuclear ERs, mediates the rapid actions of estrogens, as well as xenoestrogens such as BPA, modulating the activity of the ERK and AKT pathways, which are responsible for survival and cell death processes [66].

\subsection{Effects of BPA on MSCs}

\subsubsection{Adipogenic differentiation}

To date, there have been few studies examining the effects of BPA on MSCs. However, as noted above, it is widely believed that the main effects of BPA on cells occur in terms of hormone receptor signaling, since BPA usually acts as an estrogen mimic. Thus, it has been well documented that BPA can alter the expression of genes responsible for adipogenesis, including the adipogenic markers PPAR $\gamma$, FABP4, adiponectin, and LPL. Most of the data produced to date refer to the peroxisome proliferator-activated receptor (PPAR) family, which is a group of nuclear receptor proteins that work as transcription factors to regulate gene expression. PPARs play a key role in cell differentiation, development, and metabolism, as well as carcinogenesis in higher organisms [67]. PPAR $\gamma$, a subtype of this family, regulates fatty acids and glucose metabolism by stimulating lipid uptake and adipogenesis [68].

Fatty acid-binding proteins (FABPs) are a family of small cytoplasmic lipid- binding proteins that are involved in lipid signaling cascades [69]. It is known that the role of FABPs include fatty acid uptake, transport, and metabolism. FABP4 also referred to as adipocyte FABP, is an intracellular lipid chaperone involved in the coordination of lipid transport [70] and atherogenesis [71]. The gene expression of adiponectin, a secreted protein produced exclusively by adipocytes [72], can be regulated by several processes in adipose tissue. For example, adiponectin gene expression is increased 50-100-fold during the differentiation of 3T3-L1 adipocytes (a murine-derived cell line) $[72,73]$, indicating that adiponectin is a marker of mature adipocytes. In accordance with these data obtained with clonal preadipocytes, Lihn and collaborators [74] found that the expression of adiponectin mRNA was induced nearly 100-fold during differentiation of human preadipocytes in primary culture.

Finally, LPL gene, that encodes lipoprotein lipase, is expressed in the heart, muscle, and adipose tissues. LPL works as a homodimer, and functions both as a triglyceride hydrolase and a ligand/bridging factor for receptor-mediated lipoprotein uptake. Mutations in the LPL gene results in type I hyperlipoproteinemia deficiency, while the less extreme mutations in LPL related to many disorders of lipoprotein metabolism [75]. Lipid metabolism has a strong influence on LPL, where this gene hydrolyzes triglyceride-rich lipoproteins, such as chylomicrons or very low-density lipoprotein (VLDL), to free fatty acids that can then be incorporated into the adipose tissue for storage [76]. Thus, all these genes described above play key roles in the adipogenic differentiation, where BPA has been shown to interfere, and possibly affect such genes.

BPA has been shown to accelerate the rate of adipogenesis, as seen in the study by Masuno and co-authors [77], where BPA $(80 \mu \mathrm{M})$ induced both adipocyte differentiation and adipogenic marker genes in 3T3-L1 preadipocytes over six days. BPA also increased the amount of triglyceride accumulation during 14 days of differentiation in 3T3-L1 preadipocytes. However, when tested under the same conditions ( $80 \mu \mathrm{M}$ for 14 days; a very high dose, that does not mimic real environmental exposure levels), there was no effect on human primary preadipocytes [78]. Based on these discrepant results, we will present here a summary of the major findings of MSCs exposed to BPA during in vitro differentiation.

MSCs, especially adipose stem cells, are a useful model for studying changes in the programming of adipogenesis because they give rise to adipocyte progenitors in vivo [79]. Few studies have examined the differentiation potential of different MSCs when exposed to BPA. The concern about the possible contamination of these cells by endocrine disruptors began with the adoption of Good Manufacturing Practices (GMPs) in the processes used for the production of MSCs for therapeutic purposes. Biemann and colleagues [80] were one of the first to study the effects of endocrine-disrupting chemicals on the adipogenic differentiation of MSCs. They showed that BPA, and other EDCs such as DEHP (bis (2-ethylhexyl) phthalate) and TBT (tributyltin), affect the adipogenic differentiation of murine mesenchymal stem cells (MSC, $\mathrm{C} 3 \mathrm{H} / 19 \mathrm{~T} 1 / 2)$ in a concentration, stage of differentiation, and compound-specific manner. After 6 or 14 days of exposure, BPA $(10 \mu \mathrm{M})$ decreased the subsequent adipogenic differentiation of MSCs when cells were exposed during their undifferentiated growth phase. ChamorroGarcía and colleagues [44] also used bone marrow primary cultures of MSCs and 3T3-L1 cells to study the effects of BADGE (bisphenol A diglycidyl ether) and BPA on adipogenesis, osteogenesis, gene expression, and nuclear receptor activation. They found that exposure to BPA $(1 \mathrm{nM}, 10 \mathrm{nM}, 100 \mathrm{nM}$, and $1 \mu \mathrm{M})$ over 14 days failed to promote adipogenesis in MSCs, but did induce adipogenesis in 3T3-L1 cells, which was the same outcome that was found in Linehan's study [78]. In 2014, Biemann and colleagues [81] conducted another study with multipotent murine mesenchymal stem cells (C3H10T1/2) that were exposed to EDC mixtures at high concentrations, i.e. MIX-high $(10 \mu \mathrm{M}$ BPA, $100 \mu \mathrm{M}$ DEHP-diethylhexylphthlate, and $100 \mathrm{nM}$ TBT-Tributyltin), and in environmentally relevant concentrations, i.e. MIX-low (10 nM BPA, $100 \mathrm{nM}$ DEHP, and $1 \mathrm{nM}$ TBT). The experiment involved EDC exposure either during the entire culture time (0-12 days) or at distinct stages of the adipogenic differentiation program. The data showed that MIX-high increased the development of adipocytes and the expression of adipogenic marker genes independently of the exposure window. The total amount of glyceride content was not increased. The MIX-low had no obvious impact on adipogenesis. They found that in EDC mixtures, the adipogenic effect of TBT and DEHP predominate the effect of BPA on its own. The effect of the EDC mixture could not be deduced from single compound experiments.

With respect to ASCs, Ohlstein and collaborators [60] determined the effects of BPA on adipogenesis in cultured human ASCs, which are the precursors of mature adipocytes. Cells were exposed to increasing concentrations of BPA $(100 \mathrm{pM}-10 \mu \mathrm{M})$. BPA significantly enhanced adipogenesis at a concentration of $1 \mu \mathrm{M}$ after 21 days of culture. The authors also found BPA effects increasing estrogen receptor (ER or ESR1) transcription, and the use of an ER antagonist inhibited BPA effects, indicating its possible action via an ER-mediated pathway. In 2016, Leem and colleagues [82] conducted a study where they analyzed the effects of high BPA concentrations $(250 \mu \mathrm{M}, 500 \mu \mathrm{M}$ for $18 \mathrm{~h})$ on human bone marrow MSCs and found that BPA had a disturbing effect on $\beta$-catenin signaling via superoxide anion overload. In the same year, Wang and colleagues [66] developed a 3D model to study the action of BPA on human embryonic MSCs and compared these data with ASCs. They found that BPA did not induce adipogenesis in ASCs and furthermore did not have a significant effect on embryonic MSCs. Table 1 presents a summary of all of these data.

\subsubsection{Osteogenic differentiation}

When considering other studies related to differentiation of MSCs, there is limited information about the toxic effect of BPA towards bone health [83]. It is known that BPA may affect adult bone metabolism and its disorders, including osteoporosis through the SXR signaling in both adult and fetal bones [84]. Several in vitro studies involving cultured scales of goldfish, bone-marrow derived macrophages, RAW 264.7 cells, and MC3 T3-E1 cells, as well as an in vivo study with ovariectomized rats have shown this relation [85-90]. Thus, these recent outcomes suggest that BPA may have several effects on bone cells, including osteoblasts and osteoclasts, through multifactorial pathways [85]. Regarding the findings on osteogenic differentiation, in the year 2013, a group of researchers observed that BPA also stimulated differentiation and induced apoptosis in human osteoblasts and osteoclasts [87]. 
Table 1

Major studies on BPA effects on mesenchimal stem cells.

\begin{tabular}{|c|c|c|c|}
\hline Reference & Cell type & Aim of the study & Results \\
\hline [80] & $\begin{array}{l}\text { C3H/10T1/2 (mouse } \\
\text { embryosarcoma stem cells); } \\
\text { and } \\
\text { CGR8 (mouse embryonic stem cells). }\end{array}$ & $\begin{array}{l}\text { Analyse the BPA, DEHP and TBT effects on the adipogenic } \\
\text { differentiation of C3H/10T1/2 and CGR8 cells in a } \\
\text { concentration, stage and compound specific manner. }\end{array}$ & $\begin{array}{l}\checkmark \text { BPA }(10 \mathrm{uM}) \text { decreased adipogenic differentiation in } \\
\text { C3H/10 T1/2 cells exposed during undifferentiated } \\
\text { growth; } \\
\checkmark \text { DEHP (100 uM) enhanced adipogenesis during the } \\
\text { hormonal induction period, and TBT }(100 \mathrm{nM}) \text { in all } \\
\text { investigated stages; } \\
\checkmark \text { Any effect was seen on CGR8. }\end{array}$ \\
\hline [44] & $\begin{array}{l}\text { Mouse bone marrow stem cells, } \\
\text { Human bone marrow mononuclear } \\
\text { cells } \\
\text { and } \\
\text { 3T3-L1 mouse pre-adipocyte cells. }\end{array}$ & $\begin{array}{l}\text { Study the adipogenic capacity of BADGE and BPA and their } \\
\text { effects on adipogenesis, osteogenesis, gene expression, and } \\
\text { nuclear receptor activation. }\end{array}$ & $\begin{array}{l}\checkmark \text { BADGE promoved adipogenesis in all cell types; } \\
\checkmark \text { BPA induced adipogenesis only in 3T3-L1 cells; } \\
\checkmark \text { Neither BADGE nor BPA activated or antagonized } \\
\text { retinoid "X" receptor or PPAR } \gamma \text {. }\end{array}$ \\
\hline [78] & Human adult stem cells and T3T-L1. & Investigate BPA effects on adipogenesis of hASCs. & $\begin{array}{l}\checkmark \text { BPA (0.08uM, 8uM, 80uM) during } 14 \text { days of } \\
\text { differentiation reduced triglyceride accumulation and } \\
\text { suppressed LPL gene transcription; } \\
\checkmark \text { BPA reduced triglyceride accumulation during } \\
\text { adipogenesis by attenuating the expression of LPL gene } \\
\text { transcription. }\end{array}$ \\
\hline [60] & Human adipose derived stem cells. & Determine the effects of BPA on adipogenesis of hASCs. & $\begin{array}{l}\checkmark \text { BPA(1 mM) significantly adipogenesis after } 21 \text { days; } \\
\checkmark \text { BPA increased transcription of the ER. } \\
\checkmark \text { Treatment with the ER antagonist ICI } 182780 \text {, blocked } \\
\text { the effects of BPA. }\end{array}$ \\
\hline [81] & C3H/10T1/2. & $\begin{array}{l}\text { Investigate the effects of a simultaneous exposure of BPA } \\
(10 \mu \mathrm{mol} / \mathrm{L}) \text {, DEHP }(100 \mu \mathrm{mol} / \mathrm{L}) \text {, and TBT }(100 \mathrm{nmol} / \mathrm{L}) \text { on } \\
\text { C3H/10T1/2 differentiation into adipocytes. }\end{array}$ & $\begin{array}{l}\checkmark \text { BPA, DEHP and TBT in higher concentrations } \\
\text { increased the development of adipocytes and the } \\
\text { expression of adipogenic marker genes; } \\
\checkmark \text { BPA, DEHP and TBT in lower concentrations had no } \\
\text { obvious impact on adipogenesis. }\end{array}$ \\
\hline [82] & Human bone marrow stem cells. & $\begin{array}{l}\text { Verify if BPA }(250 \mu \mathrm{M}, 500 \mu \mathrm{M} \text { during } 18 \mathrm{~h}) \text { has cytotoxic action } \\
\text { on hBMSCs }\end{array}$ & $\begin{array}{l}\checkmark \text { BPA promoved citotoxicity in a dose and time } \\
\text { dependent manner; } \\
\checkmark \text { BPA causes a disturbance in b-catenin signaling via a } \\
\text { superoxide anion overload. }\end{array}$ \\
\hline [66] & $\begin{array}{l}\text { Human adipose derived stem cells } \\
\text { and Human embryonic derived stem } \\
\text { cells. }\end{array}$ & $\begin{array}{l}\text { Develop a 3D human tissue system able to model the effects of } \\
\text { obesogens (BPA- } 10 \mu \mathrm{M}, 20 \mu \mathrm{M}, 40 \mu \mathrm{M} \text { ) (TBT - } 1 \mathrm{nM}, 5 \mathrm{nM} \text {, } \\
10 \mathrm{nM} \text { ), (BPS - } 10 \mu \mathrm{M}, 20 \mu \mathrm{M}, 40 \mu \mathrm{M} \text { ) in vitro to better } \\
\text { understand the impact of obesogens on early development. }\end{array}$ & $\begin{array}{l}\checkmark \text { hASCs were not induced to adipogenesis and hESCs } \\
\text { didn't show any significant effect when exposed to } \\
\text { these compounds. }\end{array}$ \\
\hline
\end{tabular}

BPA: bisphenol A; DEHP: bis(2-ethylhexyl) phthalate; TBT: tributyltin; BADGE: bisphenol A diglycidyl ether; PPAR $\gamma$ : peroxisome proliferator-activated receptor gamma; LPL: lipoprotein lipase; hASCs: human adipose-derived stem cells; ER: estrogen Receptor; MSCs: mesenchymal stem cell; hBMSCs: human bone mesenchymal stem cells; hASCs: human adipose derived stem cells; hESCs: human embryonic derived stem cells.

However, the exact action of BPA on bone metabolism in adult humans is still under discussion.

BPA, a selective estrogen receptor modulator (SERM), shows different modes of actions in different types of cells and tissues, which is unlike the classical estrogenic substances [91,92]. Based in this assumption, BPA exerts its functions by binding to the estrogen receptors $\alpha \& \beta[91,94]$ and recent studies have shown that BPA also binds to the non-classical estrogen receptors to activate the estrogen-sensitive genes via non-genomic pathways [92,93]. Surprisingly, Baldwin and co-authors (1998) has found that BPA reduced cell viability significantly (80\%) with a $12.5 \mu \mathrm{M}$ dose in BG-1 ovarian adenocarcinoma cells [88].

Upon the stimulation of apoptotic signals, BPA was shown to activate the apoptotic initiators, caspase- 8 and 9 , and triggered downstream effectors, such as caspase-3, according to some studies [95,96]. In 2012, Biemann and colleagues [79] demonstrated that BPA does not induce proliferation in human ASCs. BPA induced cell death through the oxidative stress pathway in both in vitro and in vivo as demonstrated by Leem and collaborators, who observed significantly increased levels of apoptosis in human bone marrow stem cells (hBMSCs), when treated with $500 \mu \mathrm{M}$ BPA for $6 \mathrm{~h}$ or more [82]. This corroborated the previous data showing that increased oxidative stress damages several tissues including the bone tissue [97]. More recently, a study showed that a $12.5 \mu \mathrm{M}$ dose of BPA reduces differentiation and increases the apoptosis in osteoblasts and osteoclasts [83]. BPA exerts estrogen antagonistic effect on bone cells by binding to the non-classical ER $\gamma$ receptor, which reduces the activity of bone specific markers such as BMP-2 and ALP. Recent studies demonstrated that BPA disturbs the bone metabolism via the RANKL (Receptor activator of nuclear factor kappa-B ligand) pathway, apoptotic pathway, and the Wnt/ß-catenin signaling pathway. However, the exact underlying mechanism has not yet been unraveled [83].

Only one study has reported migration in MSCs that were exposed to BPA [66]. The authors tested the response of MSCs derived from uterine myoma tissue (hUM-MSCs) to BPA, in which they found that this compound was able to enhance cell proliferation and colony forming efficiency, induce COX-2 gene expression, and promote migration and invasion of hUM-MSCs.

MSCs that are exposed to BPA exert pro-inflammatory effects, and their action is evident through the paracrine effects, as well as by altering differentiation [30], with an increased expression of certain osteogenic genes such as ALP, resulting in increased mineralization [98,99]. Li and colleagues (2015) also showed that conditioned medium from TNF- $\alpha$-activated MSCs could boost osteogenesis through paracrine mechanisms [98]. In contrast, it has been demonstrated that in response to cytokine stimulation cell viability decreases and formation of bone nodules by primary osteoblasts is reduced [100]. These contrasting results could be explained by the differences in the longterm and short-term exposures to pro-inflammatory conditions. For example, in a long-term exposure study, stem cells from the apical papilla demonstrated inhibition of osteogenesis when exposed to proinflammatory cytokines (TNF- $\alpha$ and interleukin 1 beta), while the cytokines induced mineralization in the short-term culture [101]. In view of all the data presented here, we can infer that BPA acts on MSCs exhibiting inconsistent behavior and it is also clear that short and longterm exposure studies differ significantly. 


\section{Concluding remarks}

MSCs have gained attention in the field of regenerative medicine because they can potentially modulate numerous incurable diseases [102]. Currently, there are 333 published studies describing the use of MSCs in clinical trials, addressing the prospective therapies for diseases such as cardiovascular disease [103], diabetic nephropathy [101], diverse brain injuries (including stroke, neural trauma, and heatstroke) [104] and lung injury [105]. These cells are widely used because of their multiple biological functions, including multi-lineage differentiation, their ability to promote tissue-repair, as well as their anti-inflammatory and immunosuppressive effects. Since 2000, the MSC field has progressed rapidly after demonstrating that ex vivo-grown cells had immunosuppressive properties as exhibited by inflammatory cytokines such as IFN- $\gamma$, IL-1, or TNF- $\alpha$ [88], having the ability to reduce inflammation, suppress immune responses, and release trophic factors $[4,7,8]$.

Regarding their clinical properties, these cells offer several advantages, such as availability and ease of harvesting, as well as offer adequate safety, with a very low possibility of malignant transformation after infusion of allogeneic cells, which is often the case with embryonic stem cells (ESCs) and induced pluripotent stem cells (iPSCs). There is also a lack of ethical issues that usually arise with the application of human ESCs [7].

However, it is well-known that this new and exciting branch of stem cell biology has hurdles that we have yet to overcome. For example, in terms of the mechanisms underlying the biological function of MSCs, it was originally thought that cells originating from damaged tissue differentiate and replace damaged cells [3]. Nonetheless, subsequent research has shown that MSC engraftment and differentiation at the sites of injury are very low and transient [3]. Therefore, for successful cellbased therapies, a significant number of cells are needed, requiring extensive ex vivo cell expansion. Owing to the prolonged ex vivo expansion needed to obtain a sufficient number of cells for clinical therapy, long-term culture will likely evoke continuous changes in MSCs, including cellular senescence $[106,107]$. Besides this, other concerns impose limitations for the clinical use of MSCs such as the safety, efficacy, and reproducibility of MSC production, donor eligibility and screening, facilities, environmental controls, and storage [108].

Taking into consideration the environmental control, one such important sub-issue is the toxicological quality of cells. It is well-known that exposure to EDCs have a strong effect on organisms, which can change the functioning of their organs and regulatory systems. This subsequently leads to the development of short or long-term diseases. Therefore, producing cells for its use in humans in accordance to the Good Manufacturing Practices (GMPs) is a global challenge [108].

Although very few studies have been conducted to date using MSCs from different sources and species that have been exposed to BPA, all those studies have indicated an effect on the adipose differentiation process. Different authors have suggested that a source of variability might be due to the use of different cells from different animals. In addition, differences in the concentrations of BPA or the time of exposure could also be a source of variation. Most of the reported studies have exposed cells to extremely high concentrations of BPA that do not mimic the real environment.

Currently, there are various studies which have shown that BPA has an effect on the development of obesity in vivo, suggesting its putative obesogenic effects. BPA may exert obesogenic effects through various pathways, either by its activity as an estrogen and glucocorticoid receptor agonist, by its interference with the thyroid hormone pathways, by activation of the peroxisome proliferator-activated receptor-c (PPARc) [109-114], or by its role in the differentiation of human adipocytes in vitro $[14,44,60,115,116]$. Therefore, we would need to evaluate the results of more studies that use the same cell types, concentrations, and exposure times, in order to reach more solid conclusions regarding the biochemical and molecular effects of BPA on MSCs.

An assessment of the strengths and weaknesses of MSCs from ex vivo cultures could provide novel approaches to overcome limitations to their therapeutic efficacy and maximize their clinical value. Thus, it is suffice to conclude that diverse populations within the heterogeneous group of MSCs [96] could exhibit divergent behaviors when exposed to BPA or other EDCs. More systematic studies will therefore be required for further analysis.

\section{References}

[1] L. De Luca, S. Trino, I. Laurenzana, D. Lamorte, A. Caivano, L. Del Vecchio, P. Musto, Mesenchymal stem cell derived extracellular vesicles: a role in hematopoietic transplantation? Int. J. Mol. Sci. 18 (2017) 1022, http://dx.doi.org/10. 3390/ijms18051022.

[2] S.J. Hashemian, M. Kouhnavard, E. Nasli-esfahani, Mesenchymal Stem Cells: Rising Concerns over Their Application in Treatment of Type One Diabetes Mellitus, 2015 (2015), http://dx.doi.org/10.1155/2015/675103.

[3] S.G. Almalki, D.K. Agrawal, Key transcription factors in the differentiation of mesenchymal stem cells, Differentiation 92 (2016) 41-51, http://dx.doi.org/10. 1016/j.diff.2016.02.005.

[4] F. Gao, S.M. Chiu, D.A.L. Motan, Z. Zhang, L. Chen, H.-L. Ji, H.-F. Tse, Q.-L. Fu, Q. Lian, Mesenchymal stem cells and immunomodulation: current status and future prospects, Cell Death Dis. 7 (2016) e2062, , http://dx.doi.org/10.1038/cddis. 2015.327.

[5] R.S. Tuan, G. Boland, R. Tuli, Adult mesenchymal stem cells and cell-based, Tissue Eng. 5 (2003), http://dx.doi.org/10.1186/ar614.

[6] A.J. Friedenstein, I.I. Piatetzky-Shapiro, K.V. Petrakova, Osteogenesis in transplants of bone marrow cells, J. Embryol. Exp. Morpholog. 16 (1966) 381-390.

[7] M. Dominici, K. Le Blanc, I. Mueller, F.C. Marini, D.S. Krause, R.J. Deans, A. Keating, D.J. Prockop, E.M. Horwitz, Minimal criteria for defining multipotent mesenchymal stromal cells, The International Society for Cellular Therapy Position Statement, 8 2006, pp. 315-317, , http://dx.doi.org/10.1080/ 14653240600855905.

[8] E.J. Kim, N. Kim, S.-G. Cho, The potential use of mesenchymal stem cells in hematopoietic stem cell transplantation, Exp. Mol. Med. 45 (2013) e2, , http://dx. doi.org/10.1038/emm.2013.2.

[9] B. Yu, X. Zhang, X. Li, Exosomes derived from mesenchymal stem cells, Int. J. Mol. Sci. 15 (2014) 4142-4157, http://dx.doi.org/10.3390/ijms15034142.

[10] M.E. Bernardo, W.E. Fibbe, Mesenchymal stromal cells: sensors and switchers of inflammation, Cell Stem Cell 13 (2013) 392-402, http://dx.doi.org/10.1016/j. stem.2013.09.006.

[11] P.N.N. da Silva Meirelles, L. Chagastelles, Mesenchymal stem cells reside in virtually all post-natal organs and tissues, J. Cell Sci. 119 (2006) 2204-2213, http:// dx.doi.org/10.1242/jcs.02932.

[12] C. Campagnoli, I.A.G. Roberts, S. Kumar, P.R. Bennett, I. Bellantuono, N.M. Fisk, Identification of mesenchymal stem/progenitor cells in human first-trimester fetal blood, liver, and bone marrow, Blood 98 (2001) 2396-2403.

[13] Y.S. Takeda, Q. Xu, Neuronal differentiation of human mesenchymal stem cells using exosomes derived from differentiating neuronal cells, PLoS One 10 (2015), http://dx.doi.org/10.1371/journal.pone.0135111.

[14] D.C. Yeh, T.-M. Chan, H.-J. Harn, T.-W. Chiou, H.-S. Chen, Z.-S. Lin, S.-Z. Lin, Adipose tissue-derived stem cells in neural regenerative medicine, Cell Transplant. 24 (2015) 487-492, http://dx.doi.org/10.3727/096368915X686940.

[15] J.E. Morgan, T.A. Partridge, Muscle satellite cells, Int. J. Biochem. Cell Biol. 35 (2003) 1151-1156, http://dx.doi.org/10.1016/S1357-2725(03)00042-6.

[16] H. Yin, F. Price, M.A. Rudnicki, Satellite cells and the muscle stem cell niche, Physiol. Rev. 93 (2013) 23-67, http://dx.doi.org/10.1152/physrev.00043.2011.

[17] D.J. Milner, M. Bionaz, E. Monaco, J.A. Cameron, M.B. Wheeler, Myogenic potential of mesenchymal stem cells isolated from porcine adipose tissue, Cell Tissue Res. (2018) 1-16, http://dx.doi.org/10.1007/s00441-017-2764-z.

[18] P. Zuk, M. Zhu, H. Mizuno, J. Huang, J.W. Futrell, A.J. Katz, P. Benhaim, H.P. Lorenz, M.H. Hedrick, Multilineage cells from human adipose tissue: implications for cell-based therapies, Tissue Eng. 7 (2001) 211-228, http://dx.doi. org $/ 10.1089 / 107632701300062859$.

[19] A. Klimczak, U. Kozlowska, Mesenchymal Stromal Cells and Tissue-Specific Progenitor Cells: Their Role in Tissue Homeostasis, 2016 (2016), http://dx.doi. org $/ 10.1155 / 2016 / 4285215$.

[20] K.M. Safford, K.C. Hicok, S.D. Safford, Y.-D.C. Halvorsen, W.O. Wilkison, J.M. Gimble, H.E. Rice, Neurogenic differentiation of murine and human adiposederived stromal cells, Biochem. Biophys. Res. Commun. 294 (2002) 371-379, http://dx.doi.org/10.1016/S0006-291X(02)00469-2.

[21] P.H. Ashjian, A.S. Elbarbary, B. Edmonds, D. DeUgarte, M. Zhu, P.A. Zuk, H.P. Lorenz, P. Benhaim, M.H. Hedrick, In vitro differentiation of human processed lipoaspirate cells into early neural progenitors, Plast. Reconstr. Surg. 111 (2003) 1922-1931, http://dx.doi.org/10.1097/01.PRS.0000055043.62589.05.

[22] P. Bourin, B.A. Bunnell, L. Casteilla, M. Dominici, A.J. Katz, K.L. March, H. Redl, J.P. Rubin, NIH Public Access 15 (2014) 641-648, http://dx.doi.org/10.1016/j. jcyt.2013.02.006. Stromal.

[23] S. Law, S. Chaudhuri, Mesenchymal stem cell and regenerative medicine: regeneration versus immunomodulatory challenges, Am. J. Stem Cells 2 (2013) 
22-38 http://www.ncbi.nlm.nih.gov/pubmed/23671814\%5Cnhttp://www. pubmedcentral.nih.gov/articlerender.fcgi? artid = PMC3636724

[24] U.D. Wankhade, M. Shen, R. Kolhe, S. Fulzele, Advances in Adipose-Derived Stem Cells Isolation, Characterization, and Application in Regenerative Tissue Engineering, 2016 (2016), http://dx.doi.org/10.1155/2016/3206807.

[25] L. Frese, P.E. Dijkman, S.P. Hoerstrup, Adipose tissue-derived stem cells in regenerative medicine, Transfus. Med. Hemother. 43 (2016) 268-274, http://dx.doi. org $/ 10.1159 / 000448180$.

[26] J.M. Gimble, F. Guilak, B. a Bunnell, Clinical and preclinical translation of cellbased therapies using adipose tissue-derived cells, Stem Cell Res Ther 1 (2010) 19, http://dx.doi.org/10.1186/scrt19.

[27] J. Muncke, Exposure to endocrine disrupting compounds via the food chain: is packaging a relevant source? Sci. Total Environ. 407 (2009) 4549-4559, http:// dx.doi.org/10.1016/j.scitotenv.2009.05.006.

[28] A.G. Kirkley, R.M. Sargis, Environmental endocrine disruption of energy metabolism and cardiovascular risk, Curr. Diab. Rep. 14 (2014) 494, http://dx.doi.org/ 10.1007/s11892-014-0494-0.Environmental.

[29] A.S. Janesick, B. Blumberg, Obesogens: an emerging threat to public health, Am. J. Obstet. Gynecol. 214 (2017) 559-565, http://dx.doi.org/10.1016/j.ajog.2016.01. 182. Obesogens.

[30] M.E. Bateman, A.L. Strong, J.A. McLachlan, M.E. Burow, B.A. Bunnell, The effects of endocrine disruptors on adipogenesis and osteogenesis in mesenchymal stem cells: a review, Front. Endocrinol. (Lausanne) 7 (2017) 1-12, http://dx.doi.org/ 10.3389/fendo.2016.00171.

[31] A. Janesick, B. Blumberg, Obesogens, stem cells and the developmental programming of obesity, Int. J. Androl. (2012) 437-448, http://dx.doi.org/10.1111/ j.1365-2605.2012.01247.x.

[32] R.R. Newbold, E. Padilla-Banks, W.N. Jefferson, Environmental estrogens and obesity, Mol. Cell. Endocrinol. 304 (2009) 84-89, http://dx.doi.org/10.1016/j. mce.2009.02.024.

[33] M. La Merrill, L. Birnbaum, Childhood obesity and environmental chemicals, Mt. Sinai J. Med. A 78 (2011) 22-48, http://dx.doi.org/10.1002/msj.20229. CHILDHOOD.

[34] J.L. Tang-Péronard, H.R. Andersen, T.K. Jensen, B.L. Heitmann, Endocrine-disrupting chemicals and obesity development in humans: a review, Obes. Rev. 12 (2011) 622-636, http://dx.doi.org/10.1111/j.1467-789X.2011.00871.x.

[35] R.J. Kavlock, G.P. Daston, C. DeRosa, P. Fenner-Crisp, L.E. Gray, S. Kaattari, G. Lucier, M. Luster, M.J. Mac, C. Maczka, R. Miller, J. Moore, R. Rolland, G. Scott, D.M. Sheehan, T. Sinks, H.A. Tilson, Research needs for the risk assessment of health and environmental effects of endocrine disruptors: a report of the U.S. EPAsponsored workshop, Environ. Health Perspect. 104 (1996) 715-740, http://dx. doi.org/10.1289/ehp.96104s4715.

[36] E. Diamanti-kandarakis, J. Bourguignon, L.C. Giudice, R. Hauser, G.S. Prins, A.M. Soto, R.T. Zoeller, A.C. Gore, Endocrine-disrupting chemicals: an, Endocrine 30 (2009) 293-342, http://dx.doi.org/10.1210/er.2009-0002.

[37] T.T. Schug, A. Janesick, B. Blumberg, J.J. Heindel, Endocrine disrupting chemicals and disease susceptibility, J. Steroid Biochem. Mol. Biol. 127 (2011) 204-215, http://dx.doi.org/10.1016/j.jsbmb.2011.08.007.

[38] K.C. Jones, P. De Voogt, Persistent organic pollutants (POPs): state of the science, Environ. Pollut. 100 (1998) 209-221, http://dx.doi.org/10.1016/S0269-7491(99) 00098-6.

[39] K.L. Carlisle, J. Chan, D. Golub, M. Henkel, S. Painter, P. Wu, Toxicological Profile for Bisphenol A, Integr. Risk Assess. Branch Off. Environ. Heal. Hazard Assess. Calif. Environ. Prot. Agency, (2009), pp. 1-66.

[40] A.L. Wozniak, N.N. Bulayeva, C.S. Watson, Xenoestrogens at picomolar to nanomolar concentrations trigger membrane estrogen receptor- $\alpha$-mediated $\mathrm{Ca}^{2+}$ fluxes and prolactin release in GH3/B6 pituitary tumor cells, Environ. Health Perspect. 113 (2005) 431-439, http://dx.doi.org/10.1289/ehp.7505.

[41] W.V. Welshons, S.C. Nagel, F.S. Vom Saal, Large effects from small exposures. III. Endocrine mechanisms mediating effects of bisphenol A at levels of human exposure, Endocrinology 147 (2006) 56-69, http://dx.doi.org/10.1210/en.20051159.

[42] H.H. Le, E.M. Carlson, J.P. Chua, S.M. Belcher, Bisphenol A is released from polycarbonate drinking bottles and mimics the neurotoxic actions of estrogen in developing cerebellar neurons, Toxicol. Lett. 176 (2008) 149-156, http://dx.doi. org/10.1016/j.toxlet.2007.11.001.

[43] M.J. Kim, V. Pelloux, E. Guyot, J. Tordjman, L.C. Bui, A. Chevallier, C. Forest, C. Benelli, K. Clément, R. Barouki, Inflammatory pathway genes belong to major targets of persistent organic pollutants in adipose cells, Environ. Health Perspect. 120 (2012) 508-514, http://dx.doi.org/10.1289/ehp.1104282.

[44] R. Chamorro-garcía, S. Kirchner, X. Li, A. Janesick, S.C. Casey, C. Chow, A. Bisphenol, Diglycidyl ether induces adipogenic differentiation of multipotent stromal stem cells through a peroxisome, Environ. Health Perspect. 120 (2012) 984-989.

[45] F. Stossi, M.J. Bolt, F.J. Ashcroft, J.E. Lamerdin, J.S. Melnick, R.T. Powell, R.D. Dandekar, M.G. Mancini, C.L. Walker, J.K. Westwick, M.A. Mancini, Defining estrogenic mechanisms of bisphenol A analogs through high throughput microscopy-based contextual assays, Cell Chem. Biol. 21 (2014) 743-753, http://dx.doi. org/10.1016/j.chembiol.2014.03.013.

[46] A.M. Calafat, X. Ye, L.Y. Wong, J.A. Reidy, L.L. Needham, Exposure of the U.S population to bisphenol A and 4-tertiary-octylphenol: 2003-2004, Environ. Health Perspect. 116 (2008) 39-44, http://dx.doi.org/10.1289/ehp.10753.

[47] S.M. Arnold, K.E. Clark, C.A. Staples, G.M. Klecka, S.S. Dimond, N. Caspers, S.G. Hentges, Relevance of drinking water as a source of human exposure to bisphenol A, J. Expo. Sci. Environ. Epidemiol. 23 (2013) 137-144, http://dx.doi. org $/ 10.1038 /$ jes.2012.66
[48] T. Yamamoto, A. Yasuhara, H. Shiraishi, O. Nakasugi, Bisphenol A in Hazardous Waste Landfill Leachates, 42 (2001), pp. 1999-2002.

[49] I.T. Cousins, C.A. Staples, G.M. Klečka, D. Mackay, A multimedia assessment of the environmental fate of bisphenol A, Hum. Ecol. Risk. Assess. 8 (2002) 1107-1135, http://dx.doi.org/10.1080/1080-700291905846.

[50] S.J. Genuis, S. Beesoon, D. Birkholz, R.A. Lobo, Human excretion of bisphenol A: blood, urine, and sweat (BUS) study, J. Environ. Public Health 2012 (2012), http://dx.doi.org/10.1155/2012/185731.

[51] A. Maćczak, P. Duchnowicz, P. Sicińska, M. Koter-Michalak, B. Bukowska, J. Michałowicz, The in vitro comparative study of the effect of BPA, BPS, BPF and $\mathrm{BPAF}$ on human erythrocyte membrane; perturbations in membrane fluidity, alterations in conformational state and damage to proteins, changes in ATP level and $\mathrm{Na}^{+} / \mathrm{K}^{+}$ATPase and AChE activities, Food Chem. Toxicol. 110 (2017) 351-359, http://dx.doi.org/10.1016/j.fct.2017.10.028.

[52] E.C. Bonefeld-Jørgensen, M. Long, M.V. Hofmeister, A.M. Vinggaard, Endocrinedisrupting potential of bisphenol A, bisphenol A dimethacrylate, 4-n-nonylphenol, and 4- $n$-octylphenol in vitro: new data and a brief review, Environ. Health Perspect. 115 (2007) 69-76, http://dx.doi.org/10.1289/ehp.9368.

[53] J. Corrales, L.A. Kristofco, W. Baylor Steele, B.S. Yates, C.S. Breed, E. Spencer Williams, B.W. Brooks, Global assessment of bisphenol a in the environment: review and analysis of its occurrence and bioaccumulation, Dose-Response 13 (2015) 1-29, http://dx.doi.org/10.1177/1559325815598308.

[54] A. Covaci, E. Den Hond, T. Geens, E. Govarts, G. Koppen, H. Frederiksen, L.E. Knudsen, T.A. Mørck, A.C. Gutleb, C. Guignard, E. Cocco, M. Horvat, E. Heath, T. Kosjek, D. Mazej, J.S. Tratnik, A. Castaño, M. Esteban, F. Cutanda, J.J. Ramos, M. Berglund, K. Larsson, B.A.G. Jönsson, P. Biot, L. Casteleyn, R. Joas, A. Joas, L. Bloemen, O. Sepai, K. Exley, G. Schoeters, J. Angerer, M. Kolossa-Gehring, U. Fiddicke, D. Aerts, H.M. Koch, Urinary BPA measurements in children and mothers from six European member states: overall results and determinants of exposure, Environ. Res. 141 (2015) 77-85, http://dx.doi.org/10.1016/j.envres. 2014.08.008.

[55] H. Yamada, I. Furuta, E.H. Kato, S. Kataoka, Y. Usuki, G. Kobashi, F. Sata, R. Kishi, S. Fujimoto, Maternal serum and amniotic fluid bisphenol A concentrations in the early second trimester, Reprod. Toxicol. 16 (2002) 735-739, http://dx.doi.org/10. 1016/S0890-6238(02)00051-5.

[56] E.K. Vladar, Y.L. Lee, T. Stearns, J.D. Axelrod, HHS Public Access, 4 (2015), pp. 37-54, http://dx.doi.org/10.1016/bs.mcb.2015.01.016.Observing.

[57] L.N. Vandenberg, I. Chahoud, J.J. Heindel, V. Padmanabhan, F.J.R. Paumgartten, G. Schoenfelder, Urinary, circulating, and tissue biomonitoring studies indicate widespread exposure to bisphenol A, Environ. Health Perspect. 118 (2010) 1055-1070, http://dx.doi.org/10.1289/ehp.0901716.

[58] J.J. Heindel, R.R. Newbold, J.R. Bucher, L. Camacho, K.B. Delclos, S.M. Lewis, M. Vanlandingham, M.I. Churchwell, N.C. Twaddle, M. McLellen, M. Chidambaram, M. Bryant, K. Woodling, G.G. da Costa, S.A. Ferguson, J. Flaws, P.C. Howard, N.J. Walker, R.T. Zoeller, J. Fostel, C. Favaro, T.T. Schug, NIEHS/ FDA CLARITY-BPA research program update, Reprod. Toxicol. 58 (2015) 33-44, http://dx.doi.org/10.1016/j.reprotox.2015.07.075.

[59] J. Chevrier, M. Warner, R.B. Gunier, P. Brambilla, B. Eskenazi, P. Mocarelli, Serum Dioxin concentrations and thyroid hormone levels in the seveso women's health study, Am. J. Epidemiol. 180 (2014) 490-498, http://dx.doi.org/10.1093/aje/ kwu160.

[60] J.F. Ohlstein, A.L. Strong, J.A. Mclachlan, J.M. Gimble, M.E. Burow, B.A. Bunnell, Bisphenol A enhances adipogenic differentiation of human adipose stromal/stem cells, J. Mol. Endocrinol. (2014), http://dx.doi.org/10.1530/JME-14-0052.

[61] I. Porreca, L. Ulloa-Severino, P. Almeida, D. Cuomo, A. Nardone, G. Falco, M. Mallardo, C. Ambrosino, Molecular targets of developmental exposure to bisphenol A in diabesity: a focus on endoderm-derived organs, Obes. Rev. 18 (2017) 99-108, http://dx.doi.org/10.1111/obr.12471.

[62] D. Cuomo, I. Porreca, G. Cobellis, R. Tarallo, G. Nassa, G. Falco, A. Nardone, F. Rizzo, M. Mallardo, C. Ambrosino, Carcinogenic risk and bisphenol A exposure a focus on molecular aspects in endoderm derived glands, Mol. Cell. Endocrinol. 457 (2017) 20-34, http://dx.doi.org/10.1016/j.mce.2017.01.027.

[63] N. Suzuki, A. Fuse, A UV-sensitive human clonal cell line, RSa, which has low repair activity, Mutat. Res. Fundam. Mol. Mech. Mutagen. 84 (1981) 133-145, http://dx.doi.org/10.1016/0027-5107(81)90057-9.

[64] O. Takahashi, S. Oishi, Testicular toxicity of dietary 2,2-bis(4-hydroxyphenyl) propane (bisphenol A) in F344 rats, Arch. Toxicol. 75 (2001) 42-51, http://dx.doi. org/10.1007/s002040000204.

[65] D. Melzer, L. Harrie, R. Cipelli, W. Henley, C. Money, P. Mccormack, A. Young, J. Guralnik, L. Ferrucci, S. Bandinelli, A.M. Corsi, T. Galloway, Bisphenol a exposure is associated with in vivo estrogenic gene expression in adults, Environ Health Perspect. 119 (2011) 1788-1793, http://dx.doi.org/10.1289/ehp. 1103809.

[66] R.Y. Wang, R.D. Abbott, A. Zieba, F.E. Borowsky, D.L. Kaplan, Development of a three-dimensional adipose tissue model for studying embryonic exposures to obesogenic chemicals, Ann. Biomed. Eng. 45 (2017) 1807-1818, http://dx.doi. org/10.1007/s10439-016-1752-x.

[67] W. Wahli, O. Braissant, B. Desvergne, Peroxisome proliferator activated receptors: transcriptional regulator of adipogenesis, lipid metabolism and more, Chem. Biol. 2 (1995) 261-266, http://dx.doi.org/10.1016/1074-5521(95)90045-4.

[68] J.R. Jones, C. Barrick, K.-A. Kim, J. Lindner, B. Blondeau, Y. Fujimoto, M. Shiota R.A. Kesterson, B.B. Kahn, M.A. Magnuson, Deletion of PPARgamma in adipose tissues of mice protects against high fat diet-induced obesity and insulin resistance, Proc. Natl. Acad. Sci. U. S. A. 102 (2005) 6207-6212, http://dx.doi.org/ 10.1073/pnas.0306743102.

[69] L. Makowski, G.S. Hotamisligil, The role of fatty acid binding proteins in metabolic 
syndrome and atherosclerosis, Curr. Opin. Lipidol. 16 (2005) 543-548, http://dx. doi.org/10.1097/01.mol.0000180166.08196.07.

[70] M. Furuhashi, Clin. Med. Insights Cardiol., 8 (n.d.) 23-33. doi:https://doi.org/10. 4137/CMC.S17067.RECEIvED.

[71] S. Holm, T. Ueland, T.B. Dahl, A.E. Michelsen, M. Skjelland, D. Russell, S.H. Nymo, K. Krohg-Sørensen, O.P. Clausen, D. Atar, J.L. Januzzi, P. Aukrust, J.K. Jensen, B. Halvorsen, Fatty acid binding protein 4 is associated with carotid atherosclerosis and outcome in patients with acute ischemic stroke, PLoS One 6 (2011), http://dx.doi.org/10.1371/journal.pone.0028785.

[72] P.E. Scherer, S. Williams, M. Fogliano, G. Baldini, H.F. Lodish, A novel serum protein similar to C1q, produced exclusively in adipocytes, J. Biol. Chem. 270 (1995) 26746-26749, http://dx.doi.org/10.1074/jbc.270.45.26746.

[73] E. Hu, P. Liang, B.M. Spiegelman, AdipoQ is a novel adipose-specific gene dysregulated in obesity, J. Biol. Chem. 271 (1996) 10697-10703, http://dx.doi.org/ 10.1074/jbc.271.18.10697.

[74] A.S. Lihn, S.B. Pedersen, B. Richelsen, Adiponectin: action, regulation and association to insulin sensitivity, Obes. Rev. 6 (2005) 13-21, http://dx.doi.org/10. 1111/j.1467-789X.2005.00159.x.

[75] S. Kersten, Physiological regulation of lipoprotein lipase, Biochim. Biophys. Acta Mol. Cell Biol. Lipids 1841 (2014) 919-933, http://dx.doi.org/10.1016/j.bbalip. 2014.03.013.

[76] H. Wang, R.H. Eckel, Lipoprotein lipase: from gene to obesity, AJP Endocrinol. Metab. 297 (2009) E271-E288, http://dx.doi.org/10.1152/ajpendo.90920.2008.

[77] H. Masuno, J. Iwanami, T. Kidani, K. Sakayama, K. Honda, Bisphenol A accelerates terminal differentiation of 3T3-L1 cells into adipocytes through the phosphatidylinositol 3-kinase pathway, Toxicol. Sci. 84 (2005) 319-327, http://dx.doi.org/ 10.1093/toxsci/kfi088.

[78] C. Linehan, S. Gupta, A. Samali, L. O'Connor, Bisphenol A-medeiated suppression of LPL gene expression inhibits triglyceride accumulation during adipogenic differentiation of human adult stem cells, PLoS One 7 (2012) 1-11, http://dx.doi. org/10.1371/journal.pone.0036109.

[79] A.S. Avram, M.M. Avram, W.D. James, Subcutaneous fat in normal and diseased states: 2. Anatomy and physiology of white and brown adipose tissue, J. Am. Acad. Dermatol. 53 (2005) 671-683, http://dx.doi.org/10.1016/j.jaad.2005.05.015.

[80] R. Biemann, A. Navarrete Santos, A. Navarrete Santos, D. Riemann, J. Knelangen, M. Blüher, H. Koch, B. Fischer, Endocrine disrupting chemicals affect the adipogenic differentiation of mesenchymal stem cells in distinct ontogenetic windows, Biochem. Biophys. Res. Commun. 417 (2012) 747-752, http://dx.doi.org/10. 1016/j.bbrc.2011.12.028.

[81] R. Biemann, B. Fischer, A. Navarrete Santos, Adipogenic effects of a combination of the endocrine-disrupting compounds bisphenol A, diethylhexylphthalate, and tributyltin, Obes. Facts 7 (2014) 48-56, http://dx.doi.org/10.1159/000358913.

[82] J. Leem, Y.H. Oh, S. Kang, H.J. Kim, J.H. Yoon, J. Chang, BPA-toxicity via superoxide anion overload and a deficit in b-catenin signaling in human bone mesenchymal stem cells, Environ. Toxicol. 24 (2009) 296-303, http://dx.doi.org/10. 1002/tox.

[83] Z.C. Thent, G.R.A. Froemming, S. Muid, Bisphenol A exposure disturbs the bone metabolism: an evolving interest towards an old culprit, Life Sci. 198 (2018) 1-7, http://dx.doi.org/10.1016/j.lfs.2018.02.013.

[84] Y. Miki, S. Hata, S. Nagasaki, T. Suzuki, K. Ito, H. Kumamoto, H. Sasano, Steroid and xenobiotic receptor-mediated effects of bisphenol A on human osteoblasts, Life Sci. 155 (2016) 29-35, http://dx.doi.org/10.1016/j.lfs.2016.05.013.

[85] N. Suzuki, A. Hattori, Bisphenol A suppresses osteoclastic and osteoblastic activities in the cultured scales of goldfish, Life Sci. 73 (2003) 2237-2247, http://dx doi.org/10.1016/S0024-3205(03)00603-9.

[86] D. Seidlová-Wuttke, A. Schultens, H. Jarry, W. Wuttke, Urodynamic effects of estradiol (E 2) in ovariectomized (ovx) rats, Endocrine 23 (2004) 25-32, http:// dx.doi.org/10.1385/ENDO:23:1:25.

[87] S. Kanno, S. Hirano, F. Kayama, Effects of phytoestrogens and environmental estrogens on osteoblastic differentiation in MC3T3-E1 cells, Toxicology 196 (2004) 137-145, http://dx.doi.org/10.1016/j.tox.2003.12.002.

[88] W.S. Baldwin, S.W. Curtis, C A. Cauthen, J.I Risinger, K. S. Korach, J.C. Barrett, N. Carolina, N. Carolina, B.E.T. Al, BG-1 ovarian cell line: an alternative model for examining estrogen-dependent growth in vitro, In Vitro Cell Dev. Biol. Anim. 12 (1998) 649-654.

[89] M. Rucinski, A. Ziolkowska, A. Hochol, A. Pucher, C. Macchi, A.S. Belloni, G.G. Nussdorfer, L.K. Malendowicz, Estradiol and resveratrol stimulating effect on osteocalcin, but not osteonectin and collagen-1alpha gene expression in primary culture of rat calvarial osteoblast-like cells, Int. J. Mol. Med. 18 (2006) 565-570.

[90] J.K. Hwang, K.H. Min, K.H. Choi, Y.C. Hwang, I.K. Jeong, K.J. Ahn, H.Y. Chung, J.S. Chang, Bisphenol A reduces differentiation and stimulates apoptosis of osteoclasts and osteoblasts, Life Sci. 93 (2013) 367-372, http://dx.doi.org/10.1016/ j.lfs.2013.07.020.

[91] D. Agas, M.G. Sabbieti, L. Marchetti, L. Xiao, M.M. Hurley, FGF-2 enhances Runx2/Smads nuclear localization in BMP-2 canonical signaling in osteoblasts, J. Cell. Physiol. 228 (2013) 2149-2158, http://dx.doi.org/10.1002/jcp.24382.

[92] P. Diel, T. Schulz, K. Smolnikar, E. Strunck, G. Vollmer, H. Michna, Ability of xenoand phytoestrogens to modulate expression of estrogen-sensitive genes in rat uterus: Estrogenicity profiles and uterotropic activity, J. Steroid Biochem. Mol. Biol. 73 (2000) 1-10, http://dx.doi.org/10.1016/S0960-0760(00)00051-0.

[93] E.J. Routledge, R. White, M.G. Parker, J.P. Sumpter, Differential effects of xenoestrogens on coactivator recruitment by estrogen receptor (ER) alpha and ER beta, J. Biol. Chem. 275 (2000) 35986-35993, http://dx.doi.org/10.1074/jbc. M006777200.

[94] P. Alonso-Magdalena, S. Morimoto, C. Ripoll, E. Fuentes, A. Nadal, The estrogenic effect of bisphenol a disrupts pancreatic $\beta$-cell function in vivo and induces insulin resistance, Environ. Health Perspect. 114 (2006) 106-112, http://dx.doi.org/10. 1289/ehp.8451.

[95] K.H. Szymczyk, T.A. Freeman, C.S. Adams, V. Srinivas, M.J. Steinbeck, Active caspase-3 is required for osteoclast differentiation, J. Cell. Physiol. 209 (2006) 836-844, http://dx.doi.org/10.1002/jcp.20770.

[96] K.V. Floros, H. Thomadaki, D. Florou, M. Talieri, A. Scorilas, Alterations in mRNA expression of apoptosis-related genes BCL2, BAX, FAS, caspase-3, and the novel member BCL2L12 after treatment of human leukemic cell line HL60 with the antineoplastic agent etoposide, Ann. N. Y. Acad. Sci. 97 (2006) 89-97, http://dx. doi.org/10.1196/annals.1378.009.

[97] Z.K. Hassan, M.A. Elobeid, P. Virk, S.A. Omer, M. Elamin, M.H. Daghestani, E.M. Alolayan, Bisphenol a induces hepatotoxicity through oxidative stress in rat model, Oxidative Med. Cell. Longev. 2012 (2012), http://dx.doi.org/10.1155/ 2012/194829.

[98] C. Li, G. Li, M. Liu, T. Zhou, H. Zhou, Paracrine effect of inflammatory cytokineactivated bone marrow mesenchymal stem cells and its role in osteoblast function, J. Biosci. Bioeng. 121 (2016) 213-219, http://dx.doi.org/10.1016/j.jbiosc.2015. 05.017.

[99] M. Croes, F.C. Oner, M.C. Kruyt, T.J. Blokhuis, O. Bastian, W.J.A. Dhert, J. Alblas, Proinflammatory mediators enhance the osteogenesis of Human Mesenchymal stem cells after lineage commitment, PLoS One 10 (2015) 1-14, http://dx.doi.org/ 10.1371/journal.pone.0132781.

[100] L.E. Sidney, G.R. Kirkham, L.D. Buttery, Comparison of osteogenic differentiation of embryonic stem cells and primary osteoblasts revealed by responses to IL-1 $\beta$, TNF- $\alpha$, and IFN- $\gamma$, Stem Cells Dev. 23 (2014) 605-617, http://dx.doi.org/10. 1089/scd.2013.0336.

[101] Y. Liu, S.C.W. Tang, Recent Progress in Stem Cell Therapy for Diabetic Nephropathy, (2016), pp. 20-27, http://dx.doi.org/10.1159/000441913.

[102] M.F. Pittenger, A.M. Mackay, S.C. Beck, R.K. Jaiswal, R. Douglas, J.D. Mosca, M.A. Moorman, D.W. Simonetti, S. Craig, Multilineage Potential of Adult Human Mesenchymal Stem Cells and Daniel R. Marshak Published by: American Association for the Advancement of Science Stable URL, http://www.jstor.org/ stable/2899157 (REFERENCES Linked references are available on JSTOR for), 284 (2016), pp. 143-147.

[103] W. Faiella, R. Atoui, Immunotolerant properties of mesenchymal stem cells: updated review, Stem Cells Int. 2016 (2016), http://dx.doi.org/10.1155/2016/ 1859567.

[104] Y.C.Y. Hsuan, C.H. Lin, C.P. Chang, M.T. Lin, Mesenchymal stem cell-based treatments for stroke, neural trauma, and heat stroke, Brain Behav. 6 (2016) 1-11, http://dx.doi.org/10.1002/brb3.526.

[105] A.M. Katsha, S. Ohkouchi, H. Xin, M. Kanehira, R. Sun, T. Nukiwa, Y. Saijo, Paracrine factors of multipotent stromal cells ameliorate lung injury in an elastaseinduced emphysema model, Mol. Ther. 19 (2011) 196-203, http://dx.doi.org/10. 1038/mt.2010.192.

[106] J.S. Park, H.Y. Kim, H.W. Kim, G.N. Chae, H.T. Oh, J.Y. Park, H. Shim, M. Seo, E.Y. Shin, E.G. Kim, S.C. Park, S.J. Kwak, Increased caveolin-1, a cause for the declined adipogenic potential of senescent human mesenchymal stem cells, Mech Ageing Dev. 126 (2005) 551-559, http://dx.doi.org/10.1016/j.mad.2004.11.014.

[107] M.A. Young, D.E. Larson, C.W. Sun, D.R. George, L. Ding, C.A. Miller, L. Lin, K.M. Pawlik, K. Chen, X. Fan, H. Schmidt, J. Kalicki-Veizer, L.L. Cook, G.W. Swift, R.T. Demeter, M.C. Wendl, M.S. Sands, E.R. Mardis, R.K. Wilson, T.M. Townes, T.J. Ley, Background mutations in parental cells account for most of the genetic heterogeneity of induced pluripotent stem cells, Cell Stem Cell 10 (2012) 570-582, http://dx.doi.org/10.1016/j.stem.2012.03.002.

[108] L. Sensebé, M. Gadelorge, S. Fleury-Cappellesso, Production of mesenchymal stromal/stem cells according to good manufacturing practices: a review, Stem Cell Res Ther 4 (2013), http://dx.doi.org/10.1186/scrt217.

[109] D.G. Phinney, D.J. Prockop, Concise review: mesenchymal stem/multipotent stromal cells: the state of transdifferentiation and modes of tissue repair-current views, Stem Cells 25 (2007) 2896-2902, http://dx.doi.org/10.1634/stemcells. 2007-0637.

[110] G. Csanády, H. Oberste-Frielinghaus, B. Semder, C. Baur, K. Schneider, J. Filser, Distribution and unspecific protein binding of the xenoestrogens bisphenol A and daidzein, Arch. Toxicol. 76 (2002) 299-305, http://dx.doi.org/10.1007/s00204002-0339-5.

[111] B.S. Rubin, Bisphenol A: an endocrine disruptor with widespread exposure and multiple effects, J. Steroid Biochem. Mol. Biol. 127 (2011) 27-34, http://dx.doi. org/10.1016/j.jsbmb.2011.05.002.

[112] L. Trasande, T.M. Attina, J. Blustein, Association between urinary bisphenol A concentration and obesity prevalence in children and adolescents, J. Am. Med. Assoc. 308 (2012) 1113, http://dx.doi.org/10.1001/2012.jama.11461.

[113] D.S. Eng, J.M. Lee, A. Gebremariam, J.D. Meeker, K. Peterson, V. Padmanabhan, Bisphenol A and chronic disease risk factors in US children, Pediatrics 132 (2013) e637-e645, http://dx.doi.org/10.1542/peds.2013-0106.

[114] S. Ahmed, E. Atlas, Bisphenol S- and bisphenol A-induced adipogenesis of murine preadipocytes occurs through direct peroxisome proliferator-activated receptor gamma activation, Int. J. Obes. 40 (2016) 1566-1573, http://dx.doi.org/10.1038/ ijo.2016.95.

[115] J.G. Boucher, A. Boudreau, E. Atlas, Bisphenol A induces differentiation of human preadipocytes in the absence of glucocorticoid and is inhibited by an estrogenreceptor antagonist, Nutr. Diabetes 4 (2014) e102-8, http://dx.doi.org/10.1038/ nutd.2013.43.

[116] J.G. Boucher, M. Husain, A. Rowan-Carroll, A. Williams, C.L. Yauk, E. Atlas, Identification of mechanisms of action of bisphenol A-induced human preadipocyte differentiation by transcriptional profiling, Obesity 22 (2014) 2333-2343, http://dx.doi.org/10.1002/oby.20848. 